\title{
Iodine and hypothyroidism in neonates with congenital heart disease
}

\author{
N Linder, B Sela, B German, N Davidovitch, J Kuint, J Hegesh, D Lubin, J Sack
}

\begin{abstract}
Aim-To evaluate the influence of the intravenous injection of iodine during cardiac catheterisation, and of topical iodine antiseptics during surgical procedures, on thyroid function in full term neonates.

Methods-Twenty one full term infants with major cardiac anomalies who survived for more than a month were studied. Thyroxine and thyrotropin concentrations were measured (by radioimmunoassay) before each procedure, 24 hours after the procedure, and every week thereafter until the age of 1 month or until normal. Thyroxine values less than $64.4 \mathrm{nmol} / 1$ were considered low, while thyrotropin values greater than $30 \mathrm{mU} / 1$ were considered high.

Results-Thyroid function tests before iodine exposure were within normal limits in all infants. Following catheterisation or surgery six infants had raised thyrotropin concentrations; three had low thyroxine concentrations. Two of those infants were treated with L-thyroxine.

Conclusion-Iodine exposure during cardiac catheterisation or surgery may induce transient hypothyroidism in term infants.
\end{abstract}

(Arch Dis Child 1997;77:F239-F240)

Department of

Neonatology

$\mathrm{N}$ Linder

B German

$\mathrm{N}$ Davidovitch

J Kuint

D Lubin

Department of Pediatric Cardiology

J Hegesh

Department of

Pediatric

Endocrinology

J Sack

Department of Chemical Pathology

B Sela

Sheba Medical Center, Sackler School of Medicine, Tel Aviv

University, Israel

Correspondence to: Dr Nehama Linder, Department of Neonatology, Schneider Children's Medical Center,

Kaplan street 14 ,

Petach-Tikva 49202

Israel.

Accepted 3 June 1997
Keywords: iodine; hypothyroidism; cardiac malformations; catheterisation

Thyroid disorders from an excess of iodine may result from direct ingestion, absorption from the skin and mucous membranes, or from administration of organic iodine containing compounds such as radiological contrast agents. ${ }^{1}$ The purpose of this study was to evaluate prospectively the influence of the intravenous injection of iodine during cardiac catheterisation and exposure to topical iodine containing antiseptics during surgical procedures, on the thyroid function of full term neonates with major congenital cardiac malformations.

\section{Methods}

The Chaim Sheba neonatal intensive care unit is a tertiary referral centre for infants with major congenital cardiac malformations. Twenty one consecutively admitted term neonates with major cardiac anomalies (mean (SD) gestational age 39.2 (1.1) weeks and birthweight 2670 (320) g) who had survived for more than a month were studied. Table 1 details the characteristics of the cardiac anomalies and the number of cardiac catheterisations and surgical procedures during which they were exposed to iodine.

During each cardiac catheterisation 1-3 $\mathrm{ml} / \mathrm{kg}$ of Optiray 300 (Laboratoire Guerbet, France) was administered. The topical antiseptic used during surgical procedures was povidone-iodine $1 \%$, swabbed three times over the entire chest area. Blood samples for thyroxine $\left(\mathrm{T}_{4}\right)$ and thyrotropin (TSH) measurements were spotted on to filter paper before each procedure, 24 hours afterwards, and every week thereafter until the age of 1 month or until nor$\mathrm{mal} \mathrm{T}_{4}$ and $\mathrm{TSH}$ values were reached. The first urine specimen obtained after every procedure was processed for urinary iodine measurements. If this sample was not available a sample was obtained within six hours of the procedure being accepted.

$\mathrm{T}_{4}$ and TSH concentrations of blood spotted on to filter paper were measured using radioimmunoassay (neonatal $\mathrm{T}_{4}$ and $\mathrm{TSH}$, Diagnostic Product Cooperation, Los Angeles, CA, USA). $\mathrm{T}_{4}$ values less than $64.4 \mathrm{nmol} / 1$ were considered low (range of normal 64.4-231.7 $\mathrm{nmol} / \mathrm{l}$ ), while $\mathrm{TSH}$ values greater than 30 $\mathrm{mU} / 1$ were considered high ( range of normal 1-25 mU/l). Iodine measurement in urine was performed by modification of the SandellKolthoff reaction described by Dunn et al and Wawschinek et al. ${ }^{3}$ Basically, the reaction was produced by digesting urine with chlorate, followed by a catalytic reduction by iodine of $\mathrm{Ce}\left(\mathrm{SO}_{4}\right)_{2} \cdot 2\left(\mathrm{NH}_{4}\right)_{2} \mathrm{SO}_{4} \cdot 2 \mathrm{H}_{2} \mathrm{O}$ in the presence of arsenious acid. The reaction product was monitored spectrophotometrically at $405 \mathrm{~nm}$.

\section{Results}

Thyroid function tests before iodine exposure were within normal limits in all infants. Between two and 24 days afterwards (catheterisation or

Table 1 Number of cardiac catheterisations and surgical procedures

\begin{tabular}{lcccc}
\hline & $\begin{array}{l}\text { No of } \\
\text { infants }\end{array}$ & $\begin{array}{l}\text { No of } \\
\text { catheterisations }\end{array}$ & $\begin{array}{l}\text { No of } \\
\text { surgical } \\
\text { procedures }\end{array}$ & $\begin{array}{l}\text { Total no of } \\
\text { procedures }\end{array}$ \\
\hline Coarctation & 4 & 5 & 4 & 9 \\
TGA & 3 & 2 & 3 & 5 \\
PS/PA & 10 & 8 & 8 & 16 \\
VSD & 1 & 1 & & 1 \\
TA & 1 & 1 & 1 & 2 \\
TOF & 1 & 1 & & 1 \\
ASD+AV & 1 & 1 & 2 & 3 \\
Fistula & 1 & 19 & 18 & 37 \\
Total & 21 & 19 & &
\end{tabular}

PS pulmonary stenosis; PA pulmonary atresia; TGA transposition of great arteries;VSD ventricular septal defect; TA tricuspid atresia; TOF tetralogy of
defect; AV fistula-arteriovenous fistula. 
Table 2 Infants with abnormal thyroid function tests following cardiac catheterisation or surgery

\begin{tabular}{|c|c|c|c|c|c|c|}
\hline Diagnosis & $\begin{array}{l}\text { Catheterisation } \\
\text { age (days) }\end{array}$ & $\begin{array}{l}\text { Surgery age } \\
\text { (days) }\end{array}$ & $\begin{array}{l}\text { *Age } \\
\text { (days) }\end{array}$ & $\begin{array}{l}\text { T4 } \\
\text { (nmol/l) } \\
\text { (lowest) }\end{array}$ & $\begin{array}{l}\text { TSH } \\
\text { mIU/l } \\
\text { (highest) }\end{array}$ & Follow up \\
\hline VSD & 15 & & 25 & 117.1 & 69 & Normal at 55 days \\
\hline TGA & 1 & 2 & 15 & 139.0 & 89 & Lost to follow up \\
\hline Coarctation & $2,10,57$ & 4,59 & 15 & 82.3 & 60 & Normal at 63 days \\
\hline PS & 2 & 14,15 & 15 & 82.3 & 63 & Normal at 37 days \\
\hline PS & 2 & 7,14 & 4 & 51.5 & 27.9 & Normal at 22 days \\
\hline Coarctation & 2 & 5 & 26 & 48.9 & $>200$ & $\begin{array}{l}\text { Treatment for } 10 \\
\text { months }\end{array}$ \\
\hline TOF & 2 & & 9 & 27.0 & 110 & $\begin{array}{l}\text { Treatment for } 6 \\
\text { months }\end{array}$ \\
\hline
\end{tabular}

*Age at which disturbed thyroid function first noted; PS pulmonary stenosis; PA pulmonary atresia; TGA transposition of great arteries; VSD ventricular septal defect; TA tricuspid atresia;TOF tetralogy of Fallot; ASD atrial septal defect; AV fistula-arteriovenous fistula.

surgery), six infants had raised TSH values (>30 mU/1), three of whom also had low $\mathrm{T}_{4}$ values $(<64.4 \mathrm{nmol} / \mathrm{l})$ (table 2$)$. In four of these infants thyroid function tests were normal at the age of 22 to 63 days, while two infants required L-thyroxine treatment for six and 10 months, respectively. The decision to treat these infants with thyroxine was based on both low $\mathrm{T}_{4}$ and high $\mathrm{TSH}$ values. There were no significant differences between the seven infants with disturbed thyroid function tests and the 14 infants who had normal thyroid function tests in terms of birthweight, gestational age, days of mechanical ventilation, days of oxygen treatment or incidence of sepsis. The concentration of iodine found in the urine of the 21 infants ranged between 55000 to $1200000 \mu \mathrm{g} / 1$ (normal concentration $<100 \mu \mathrm{g} / 1$ in our population). The seven infants with abnormal thyroid function tests underwent a mean of 2.4 procedures compared with 1.4 procedures in infants with normal tests, but this difference was not significant by Student's $t$ test (table 1).

\section{Discussion}

Exposure to large amounts of iodine induced hypothyroidism in term infants undergoing cardiac catheterisation or surgical procedures. Transient hypothyroidism has been reported in babies undergoing cardiac catheterisation, with a decline in total $T_{4}$ values from baseline for at least seven days after the procedure, which was associated with a transient increase in $\mathrm{TSH}^{4}$ Transcutaneous iodine absorption in infants undergoing cardiac operation has also been reported. ${ }^{5}$

The phenomenon of transient hypothyroidism caused by exposure to high doses of iodine is known as the Wolff-Chaikoff effect. ${ }^{6-8}$ A mature thyroid gland is supposed to escape from inhibition after about 48 hours. ${ }^{7}$ This escape phenomenon normally develops during the neonatal period. Delay in the development of autoregulation and impaired organic iodine formation in the neonatal period accounts for iodine induced hypothyroidism in infants exposed to large amounts of iodine. ${ }^{9-11}$

The presence of low $\mathrm{T}_{4}$ caused by adaptive depression of thyroid function in term neonates with severe illness or haemodynamic complications is difficult to differentiate from pathological iodine induced thyroid dysfunc- tion. An increase in TSH is the most important diagnostic tool for this differentiation.

In this study it was impossible to differentiate between the relative contribution of intravenous iodine administration and topical iodine absorption. In addition to the iodine injected during catheterisation, significant quantities of iodine from topical disinfection may have been absorbed, due to the relatively small amount of subcutaneous tissue ${ }^{12}$ and a higher surface area:weight ratio in neonates. ${ }^{13}$ The number of procedures performed tended to be higher in the cases where thyroid dysfunction was found, possibly reflecting a dose related effect, but a significant association between the dose of iodine administered and thyroid dysfunction was not found.

In conclusion, iodine absorption from iodine containing contrast agents during cardiac catheterisation or from iodine containing topical antiseptics may cause disturbances in thyroid function in full term infants. As thyroid hormones have an important role in the normal neurological development of infants, this transient disturbance in thyroid function may be detrimental. It is thus recommended that attempts should be made to reduce the amount of iodine used during procedures and to carefully monitor thyroid function in all neonates exposed to an excess of iodine.

We are grateful to Mrs Ilsa Katz for her support, to Mrs Pnina Lilius of the Department of Statistics, Tel Aviv University, for performing the data analysis, and to Mrs Ora Amado and Mrs Judith Bruck from the Central Endocrinology Laboratory for their excellent technical assistance.

1 Silva JE. Effects of iodine containing compounds on thyroid function. Med Clin North Am 1985;69:881-98.

2 Dunn JT, Crutchfield HE, Gutekunst R. Dunn AD. Two simple methods for measuring iodine in urine. Thyroid 1993;3:119-23.

3 Wawschinek O, Eber O, Petek W, Wakonig P, Gurakar A. Bestimmung der harnjodansscheidung mittels einer modifizierten Cer-Arsenitmethode. Berichte OGKC 1985; 8:1315.

4 L'Allemand D, Gruters A, Beyer P, Weber B. Iodine in contrast agents and skin disinfectants is the major cause for hypothyroidism in premature infants during intensive care. Horm Res 1987;28:42-9.

5 Mitchell IM, Pollock JC, Jamieson MP, Fitzpatrick NC, Logan RW. Transcutaneous iodine absorption in infants undergoing cardiac operation. Ann Thorac Surg 1991;52:1138-40.

6 Theodoropoulos T, Braverman LE, Vagenakis AG. Iodine induced hypothyroidism. a potential hazard during perinatal life. Science 1979;205:502-3.

7 Fisher DA. Thyroid physiology in the perinatal period and during childhood. In: Braverman LE, Utiger RD, eds. The thyroid. Philadelphia: JB Lippincott Company, 1991: thyroid. $1207-18$.

8 L'Allemand D, Gruters A, Heideman PH, Schurbrand P. Iodine-induced alterations of thyroid function in newborn infants after prenatal and perinatal exposure to povidone iodine. F Pediatr 1983;102:935-8.

9 Pyati SP, Ramamurthy RS, Krauss MT, Pildes RS. Absorption of iodine in the neonate following topical use of povidine-iodine. $\mathcal{F}$ Pediatr 1977;91:825-8.

10 Smerdely P, Boyages SC, Wu D, et al. Topical iodine containing antiseptics and neonatal hypothyroidism in very-low birthweight infants. Lancet 1989; ii:661-4.

11 Vilain E, Bompard Y, Clement K, Laplanche S, De Kerma$\operatorname{dec} \mathrm{S}$, Aufrant C. Brief antiseptic application of iodine in neonatal intensive care units; effects on thyroid function. Arch Pediatr 1994; 1:795-800.

12 Delange F, Bourdoux P, Ermans A. Transient disorders of thyroid function and regulation in preterm infants. Pediatric and Adolescent Endocrinology. 1983;14:369-93.

13 Choonara I. Percutaneous drug absorption and administration. Arch Dis Child 1994;71:F73-4. 